以上のように，供試したカメムシ類は，いずれも調查 植物における茎葉部分での幻虫の発育は困難で花穂部分 が良好であり，成幼虫の選好程度も出穂開花後の植物に 高いことが慧められた。また，その寄主植物の種類はカ メムシの種によっていくらか異なり, クモへリカメムシ ではイネ科植物のみに限られたがこナミアオカメムシ ではイネ科，タデ科，アブラナ科，マメ科，ナス科植物，
ホソハリカメムシおよびトゲシラホシカメムシではイネ 科，タデ科など広範囲にわたることが明らかとなった。 これらのことから, 水田内外の各種植物，とくにその出 穗後のものが繁殖源とみなされ，最近に㧍ける栽培作物 の多様化と休耕田なぞの雑草繁茂が, 吸穂珄カメムシ類 の增殖した一要因になっているものと考えられる。

\title{
カメムシ類の生態ならびに防除に関する研究
}

第 3 報 ミナミアオカメムシおよびクモヘリカメムシの越冬

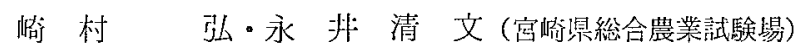

ミナミアオカメムシの越冬については魴島ら (1963) および桐谷ら（1970）の報告があり，かなり明確にされ ているが，クモへリカメムシではをの報告が少なく，不 明確な点が多い。䇤者らはミナミアオカメムシの越冬を 再確認し，さらにクモヘリカメムシの越冬を明確にする ため，1974〜76年にかけて越冬に関する実験ならびに野 外調查を行なったので，その結果の概恐を報告する。

\section{調查方 法}

1974拉よび75年に本場内の畑地にサラン網わく（面皘 $20 \mathrm{~m}^{2}$ ，高さ $2 \mathrm{~m}$ ，網目16メッシュ）を設置し，その中に 各種植物を栽植して，10〜11月にミナミアオカメムシと クモヘリカメムシの成出（1974年は野外水稻で採集した 成虫, ’75年は場内の網方く内水稻に野外採集の幼出を持 ち込み羽化した成虫）をそれぞれ一定数放飼して，その 越冬状況を観察した。また，同年に県内の主要地点 $(21$ 市町）から各種の環境 1,700䇢所を選定し，11月から翌 年 3 月にかけてすくいとり法（径 $36 \mathrm{~cm}$ ，捕出網50回振り）, ビーティング法（径 $1.3 \mathrm{~m}$, 円形布張り，1樹または $10 \mathrm{~m}^{2}$ の落下虫受止め)，上みとり法 ( $3.3 \mathrm{~m}$ または 1 樹)およ

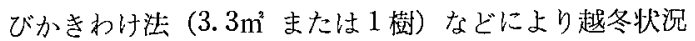
を調查した。なお，クモへリカメムシでは前記調査のほ か, 農語近辺山林内の樹木枝葉および雑草茥葉にサラン 網被覆（16メッシュ）を行ない，9〜10月に一定数の成 虫を放飼してその後の経過安観察した。

\section{結果および考察}

ミナミアオカメムシの調查結果は第 1 ～俵に示すと おりである。すなうち，その越冬場所はかなり広範团に わたり，網わく内放飼虫ではわら束の内部，網わく（材 料）板，たるき，鉄骨の接目や間隙，シュ口樹の心部や
第 1 表 ミナミアオカメムシの網わく内 故瞲による越冬

\begin{tabular}{|c|c|c|c|c|c|c|}
\hline \multirow[b]{2}{*}{ 生 息筬 所 } & \multicolumn{3}{|c|}{ 1974年放飼 } & \multicolumn{3}{|c|}{ 1975年放飼 } \\
\hline & $\mid \begin{array}{c}1975 \text { 年 } \\
1 \text { 月中 } \\
\text { 旬 }\end{array}$ & 2 月 & 每 3 月中 & $\begin{array}{l}1976 \text { 年 } \\
1 \text { 月中 } \\
\text { 旬 }\end{array}$ & {$\left[\begin{array}{l}1976 \text { 年 } \\
2 \text { 月中 } \\
\text { 旬 }\end{array}\right.$} & $\begin{array}{l}3 \text { 月 } \\
\text { 目 }\end{array}$ \\
\hline 、ク サ 1 & 27.5 & 14.3 & 19.5 & 4.5 & 5.0 & 3.6 \\
\hline カン ラ & 0 & & & & & . \\
\hline ス & & & & & & 5. \\
\hline ガ & & & & 1.7 & & 1.8 \\
\hline 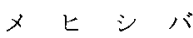 & $\mathrm{c}$ & & & & & \\
\hline 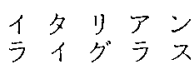 & 0 & 0 & 0 & 0 & 0.6 & \\
\hline ミゾソ バ & 0 & & 0 & 6.8 & 4. & 0.9 \\
\hline 1 ヌ タ & ( & & & & & \\
\hline ス イ バ & c & & 0 & 8. & 1 & 8. \\
\hline その他檴荤 & 0 & 0 & 0 & 0.6 & 1. 1 & 1.2 \\
\hline$\dot{z} \quad \square$ & 25.0 & 35.7 & 4.4 & 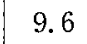 & & 8. \\
\hline 稲 & 0 & 0 & & 0.6 & 1.7 & 1. \\
\hline ら & 32.5 & 25.0 & 46.3 & 11.3 & 16.7 & 30.1 \\
\hline 落 & 0 & 0 & 0 & & 0 & \\
\hline サラン 網 & 0 & 0 & 2.4 & 9.6 & 4.4 & 1.8 \\
\hline $\begin{array}{l}\text { 網わく，鉄骨， } \\
\text { 板,タル゙間隙 }\end{array}$ & 15.0 & 14.2 & 0 & 35.6 & 39.4 & 32.8 \\
\hline そ $\quad$ o 他 & 0 & 0 & 0 & 1.1 & 0.6 & 1.8 \\
\hline 全 & & & & $\begin{array}{l}14 . \overline{2} \\
(177)\end{array}$ & $\left|\begin{array}{c}14.5 \\
(180)\end{array}\right|$ & $\begin{array}{l}17 . \\
(23\end{array}$ \\
\hline
\end{tabular}

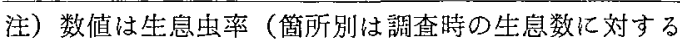
割合，全体は放柃数比対守万割合)，(）内数值は 生息虫数。1974年は11月 7 日 500 頭放飼，1975年㹥 10月 1 日 400 頭， 10 月 11 日 200 頭，10月21日200頭， 11 月 1 日 245 頭, 11 月 11 日 100 頭, 11 月 21 日 100 頭, 計 1,245 頭放餽。 
第 2 表 ミナミアオカメムシの野外における越冬状海

\begin{tabular}{|c|c|c|c|c|c|c|c|c|c|c|c|c|c|c|}
\hline \multirow{3}{*}{\multicolumn{4}{|c|}{ 調 查 環 境 }} & \multirow{3}{*}{ 調查植物 } & \multirow{3}{*}{ 調查方法 } & \multirow{3}{*}{\multicolumn{2}{|c|}{$\mid \begin{array}{l}\text { 調 查越 冬 } \\
\text { 地点数|地点数 }\end{array}$}} & \multicolumn{4}{|c|}{ 越 } & 地 & \multicolumn{2}{|l|}{ 点 } \\
\hline & & & & & & & & \multirow{2}{*}{$\begin{array}{l}\text { 調查簿 } \\
\text { 数 (本) }\end{array}$} & \multirow{2}{*}{$\begin{array}{l}\text { 生息简 } \\
\text { 所 } \\
\text { 数 }\end{array}$} & \multirow{2}{*}{$\begin{array}{r}\text { 同割合 } \\
(\%)\end{array}$} & \multirow{2}{*}{$\begin{array}{l}\text { 総生息 } \\
\text { 贵 数 }\end{array}$} & \multicolumn{3}{|c|}{1 筆あたり生息虫数 } \\
\hline & & & & & & & & & & & & 最高 & 最低 & 平均 \\
\hline 畑 & 地 & ・畦 & & シ & & 17 & 6 & (79) & (38) & 48.1 & 93 & & 1 & 2.5 \\
\hline 水 & 田 & • 硅 & 畔 & $\dot{~}$ & よみとり & 7 & 4 & (22) & (13) & 59.1 & 23 & 5 & 1 & 1.8 \\
\hline 水 & 田 & - 畑 & 地 & 白 菜, 大 根 & よみとり & 16 & 1 & 3 & 1 & 33.3 & 1 & 1 & 1 & 1.0 \\
\hline 水 & & & 田 & 積 わ ら & とり & 5 & 1 & 1 & 1 & 10.0 & 1 & 1 & 1 & 1.0 \\
\hline 庭 & $\cdot$ & 街 & & キミガョラン & よみとり & 12 & 7 & $(49)$ & (21) & 42.9 & 40 & 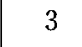 & 1 & 1.9 \\
\hline 发: & . & 街 & & $\exists \quad \beth$ ス & よみとり & 5 & 5 & $(89)$ & (46) & 51.7 & 79 & 4 & 1 & 1.7 \\
\hline 时斯 & 畔. & - 休耕 & & ガ & 引け & 15 & 6 & 24 & 7 & 29.2 & 7 & 1 & 1 & 1.0 \\
\hline & 防 & - 薄 & & ス & かきわけ & 18 & 6 & 46 & 8 & 17.4 & 8 & 1 & 1 & 1.0 \\
\hline & 滳地 & - 防風 & & x & ビーティング & 18 & 2 & 7 & 2 & 28.6 & 3 & 2 & 1 & 1.5 \\
\hline & 園地 & - 防㸡 & & 七, $\neq$ & ビーティング & 15 & 3 & 8 & 3 & 37.5 & 9 & 7 & 1 & 3.0 \\
\hline 不 & & • ヒ' & & $\mid \begin{array}{l}\text { ジシダ, フュイ } \\
\text { チゴ, チヂミザサ }\end{array}$ & すくいとり & 78 & 2 & 29 & 2 & 6.9 & 2 & 1 & 1 & 1.0 \\
\hline 小 & & & 屋 & 板帮 & よみとり & 4 & 1 & 10 & 1 & 10.0 & 1 & 1 & 1 & 1.0 \\
\hline
\end{tabular}

注）数俏は1974年12月〜1975年 3 月および1975年12月～1976年 3 月調盉の総合結果。越冬の確認されなかった 環境は省狢。

近くの葉柄基部，ススキ，チガヤのそう生した株元，八 クサイ，カンランおよびスイバの生葉や葉柄の間などで の越冬が梁められた。また，野外では水田，畑地の畦畔， 庭，街路などに栽植されているシュロ，ココスおよびキ ミガョランの心部や近くの葉柄基部，休耕址，堤防，畦 畔などにそう生しているススキ，チガヤの株元，樹園地 の防風垣や但家の生垭となっているスギ，ヒノキの樹冠 㰾枝葉，スギ，七ノキ林内の下草，八クサイ，ダイコン の生葉間，および野䅡わらの队部などでの成虫倳冬が確 認され,ことに, 畦怑, 庭, 街路などに栽植されている シュロ, ココス, キミガョラン, 防風填や住家の生坦と なっているスギ，ヒノキでは集合している個体もあり， 越冬量が多加った。なお，越冬が確誌された場所は比較 的温湿度の較塑が少ない乾燥した場所で，その越冬非態 はす心゙て成出であり，八クサイ，カンラン，スイバ以外 ではいずれも越冬色となり，絶食にかなり耐えているよ うであった。これらの結果は，鮫島ら (1963) および桐 谷ら（1970）の報告とほぼ一致しており，ミナミアオカ メムシは成虫態で主にシュロ，ココスキきガョランお よびスギやヒノキなどについて越冬するものといえる。

クモへリカメムシの調笪結果は第 3 〜 䟠に示すとお りである。すなわち，網わく内放飼虫ではススキ，チガ ヤの生荤葉，ハクサイ，カンラン，スイバなどの生葉㗊 面や葉間，およびヒノキの枝葉に集って越冬し，その量 は日陰の部分で水分の蒸散が少ないか，或いは水分摂取
の可能な箇所に多いことが認めら扎た。また，野外では 水田に隣接した比較的風当りや温湿度の較差方少ない林 地のスギ，七ノキの枝葉，その樹間に自生しているミゾ シダ，コシダ，チデミザサ，フユイチゴの荃葉，および 果樹蜠の防風埴や住家の生埴となっているスギ，七ノキ

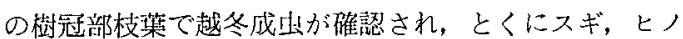
キ枝葉での密度が高い傾向にあった。なお，㟽試近边で 山林内の樹不枝葉，および雑草草葉に放飼した成业の越 冬は，各供試植物ともによく，特にスギ，上ノキの枝葉 とミゾシダ，チヂミザサ，フユイチゴの混生茎葉がすぐ れた。このような結果からみて，クモへリカメムシは成 虫態で水田近接のスギ，とノキなどの林地，その樹木枝 葉や下草，および防風垣などのスギ，ヒノキの樹冠部で 越冬するが，その越冬には風当りや温湿度の較苃が少な く，体内水分の晩脱を防ぐか，または昅汁補給し得る条 件が必要であると思われる。

以上，ミナミア才カメムシおよびクモへリカメムシの 越冬形態とその越冬場所を確認し得たが，ミナミアオカ メムシでは，主に比較的温湿度の較差が少なく乾燥した 場所のシュロ, ココス, キミガヨランの心部や近くの葉 柄基部およびスギ，ヒノキの樹冠部枝葉などで越冬し， また，クモへりカメムシは風あたりや温湿度較差が少な い曰㓌の場所，つまり湿度が高く体内水分が晩脱しない かあるいは吸汁補給し得る場所のスギ，七ノキ林地の 樹木枝葉と下草および防風垣などのスギ，七ノキの樹冠 
第 3 表 クモヘリカメムシの網わく内放

飼迈越冬

\begin{tabular}{|c|c|c|c|c|c|c|}
\hline \multirow[b]{2}{*}{ 生 息 筒 所 } & \multicolumn{3}{|c|}{ 1974年放飼 } & \multicolumn{3}{|c|}{ 1975年放飼 } \\
\hline & $\begin{array}{l}\text { 1975年 } \\
\text { 1月中 } \\
\text { 旬 }\end{array}$ & $\begin{array}{l}1975 \text { 年 } \\
2 \text { 月中 } \\
\text { 旬 }\end{array}$ & $\begin{array}{l}1975 \text { 年 } \\
3 \text { 月中 } \\
\text { 旬 }\end{array}$ & $\begin{array}{l}1976 \text { 年 } \\
1 \text { 月中 } \\
\text { 旬 }\end{array}$ & $\begin{array}{l}1976 \text { 年 } \\
2 \text { 月中 } \\
\text { 旬 }\end{array}$ & $\begin{array}{l}1976 \text { 年 } \\
3 \text { 月中 } \\
\text { 旬 }\end{array}$ \\
\hline 八クサイ & $2.5 \mid$ & $|33.3|$ & $|22.2|$ & 0.6 & 0.8 & 0 \\
\hline カン ラン & 0.5 & 0 & 11.1 & 2.6 & 0 & 2.3 \\
\hline ス ス $\neq$ & 0 & 0 & 0 & 21.2 & 14.8 & 22.9 \\
\hline チ ガ ヤ & 40.0 & 16.7 & 33.3 & 21.8 & 28.1 & 45.8 \\
\hline メ ヒ シ バ & 0 & 0 & 0 & 1.9 & 0 & 0 \\
\hline 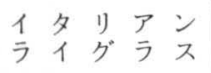 & 0 & 0 & 0 & 0 & 0 & 1.5 \\
\hline カヤッリグサ & 35.0 & 0 & 0 & 0 & 0 & 0 \\
\hline 1 又夕 デ & 0 & 0 & 0 & 0 & 0 & 0 \\
\hline ス 1 ハ & 12.5 & 33.3 & 22.2 & 23.7 & 21.1 & 0.8 \\
\hline その他雑草 & 1.0 & 16.7 & 11.1 & 4.5 & 15.6 & 10.7 \\
\hline 七, $\neq$ & - & - & - & 3.9 & 15.6 & 15.3 \\
\hline 稻 & 5.0 & 0 & 0 & 1.9 & 0 & 0 \\
\hline 束 & 1.0 & 0 & 0 & 0.6 & 0 & 0 \\
\hline 落葉 & 0 & 0 & 0 & 0 & 0 & 0 \\
\hline サラン 網 & 1.5 & 0 & 0 & 11.5 & 2.3 & 10.8 \\
\hline $\begin{array}{l}\text { 網わく, 鉄骨, } \\
\text { 板, 夕ルキ }\end{array}$ & 1.0 & 0 & 0 & 5.8 & 1.6 & 0 \\
\hline そ $の$ 他 & 0 & 0 & 0 & 0 & 0 & 0 \\
\hline 全 & $\begin{array}{l}20.0 \\
(200)\end{array}$ & $\begin{array}{l}1.2 \\
(12)\end{array}$ & $\begin{array}{c}0.9 \\
(9)\end{array}$ & $\begin{array}{l}20.0 \\
(156)\end{array}$ & $\begin{array}{l}16.4 \\
(128)\end{array}$ & $\begin{array}{l}16.8 \\
(131)\end{array}$ \\
\hline
\end{tabular}

注）数値は生息虫率（筒所別は調査時の生息数に対する 割合，全体は放飼数に対する割合)。

（）内数值は生息虫数。1974年は 11 月 7 日 1,000 頭 放飼，1975年は10月 1 日 200 頭，10月11日190頭，10 月 21 日 190 頭，11月 1 日 200 頭，計 780 頭放飼。
第 4 表 クモヘリカメムシの山林内放飼による越冬

\begin{tabular}{|c|c|c|c|}
\hline \multirow[b]{2}{*}{ 区 } & \multirow[b]{2}{*}{ 別 } & 1974年放飼 & 1975年放飼 \\
\hline & & $\begin{array}{l}\text { 1975年 } \\
4 \text { 月上旬 }\end{array}$ & $\begin{array}{l}1976 \text { 年 } \\
4 \text { 月上旬 }\end{array}$ \\
\hline ス & ギ（枝葉） & 80 & 75 \\
\hline 匕, & キ（枝葉） & - & 75 \\
\hline 力 & シ（枝葉） & - & 60 \\
\hline ネズミモ & チ（枝葉） & - & 50 \\
\hline ミゾシ & ダ（茎葉） & 90 & 70 \\
\hline 千 カ & ヤ （茥葉） & 60 & 58 \\
\hline $\begin{array}{l}\text { ミゾシダ, } \\
\text { フユイチゴ }\end{array}$ & $\begin{array}{l}\text { チヂミザサ, } \\
\text { (苯葉)* }\end{array}$ & 70 & 85 \\
\hline
\end{tabular}

注）数值は放飳虫数に対する生存割合（3区平均） * $3 \mathrm{~m}^{2}$ の網わく使用。

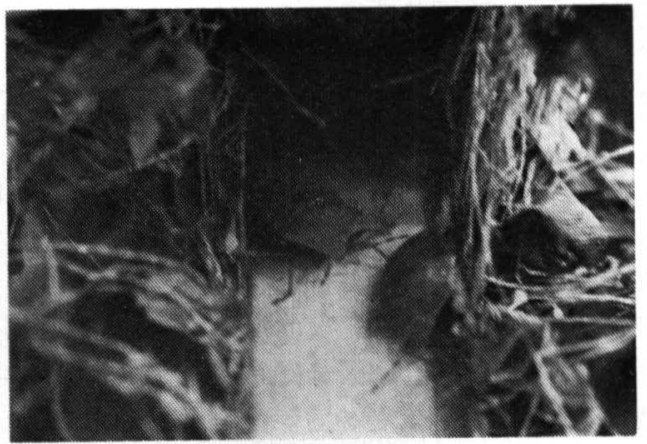

第 1 図 ココスで越冬しているミナミアオカメム シ成虫

第 5 表 クモへリカメムシの野外における越冬状況

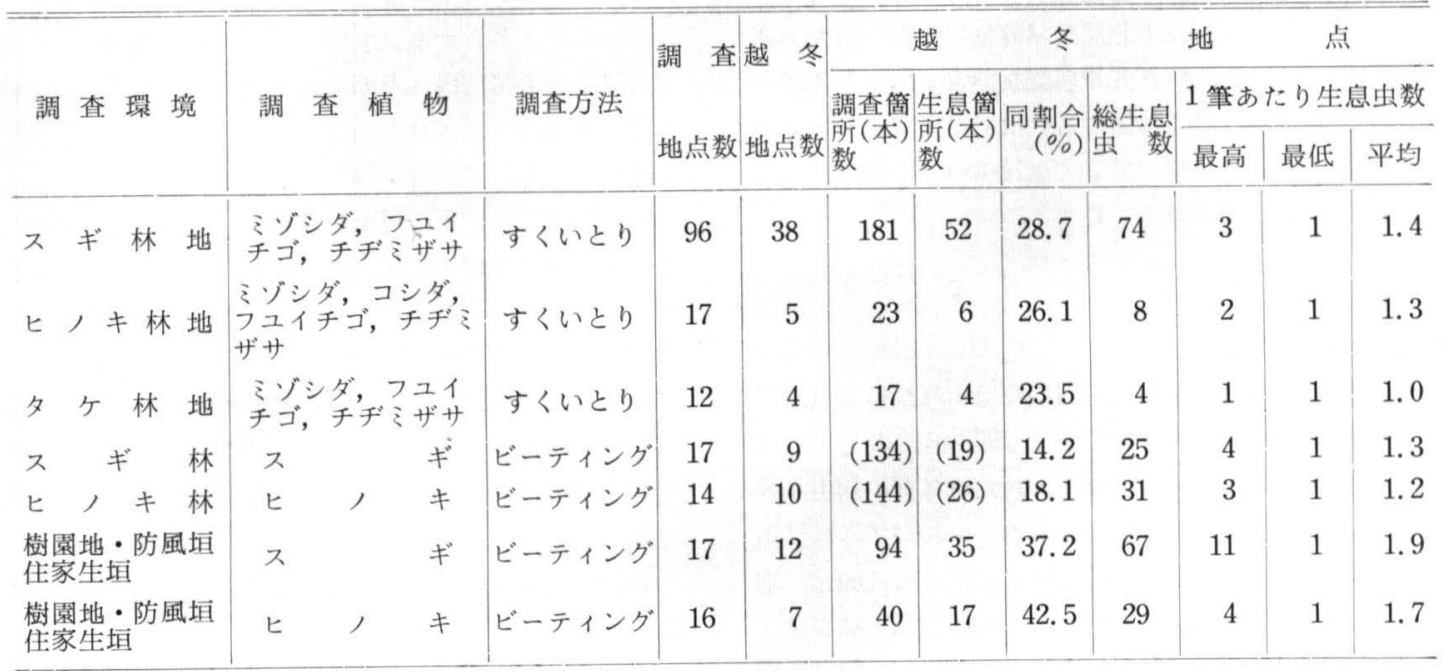

注）数值は1974年12月〜1975年 3 月および1975年12月～1976年 3 月調査の総合結果。越冬の確認されなかった 環境は省略。 


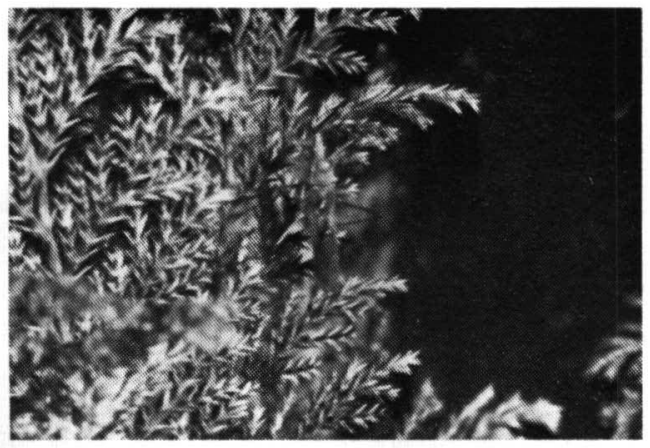

第 2 図 スギで越冬しているクモへリカメムシ成虫
部で越冬するものと思われる。なお，今後は主要場所に 㧍ける越冬量の把握と発生予察法の確立について検討を 進めていきたい。

\section{引用 文 献}

1）桐谷圭治・法橋信彦(1970) 農林水产技術会議指定試 験（病害虫）9：260p.

2) 鮫島徳造・永井清文 （1963）宮崎総合農試研報2：40-51.

\title{
福岡県における山形産 (庄内型) ニカメイガの飼育結果
}

\author{
立石 礨・酒井久夫・野田政春（福岡県立農業試験場）
}

東北から北陸地方に分布する庄内型ニカメイガを福岡 に移して，自然条件下で飼育する機会を得た。すなわち， 筆者らは1973年と1974年に山形産（庄内型）を福岡の自 然条件で越冬させ, 第 1 回成虫の発生期, 異った時期の 自然日長下での蛹化状況や累代飼育の影響などについて 調査を行った。以下，その餇育結果の概要を報告する。 本文に入るに先だち，材料を提供され終始助言を睗わ った九州病害虫防除推進協議会長末永一博士, 研究推進 上に便宜を与えられた福岡県立農業試験場病虫部長横山 佐太正博士に厚く感謝の意を表する。また文献を恵与さ れ研究に当り教示いただいた四国農業試験場釜野静也博 士，取りまとめについて有益な助言と教示をいただき， な拉文献を与兄られた東北農業試験場岸野賢一博士，文 献を貸与していただいた九州農業試験場平尾重太郎博士 に対し，それぞれ深く感謝する。山形県農業試験場庄内 支場布施寛氏には材料の採集，送付について寄せられた 御好意に対し深甚の謝意を表する。

\section{1. 材 料 と 方 法}

\section{1) 材 料}

調查に用いた山形産虫（庄内型）は山形県農業試験場 庄内支場の布施寛氏が，1972 年と 1973 年の 12 月上旬に 山形県鶴岡市滝沢において採集された越冬前の幼虫を福 岡に移し, 福岡県農業武験場の飼育室において, 自然条 件下で越冬させたものである。越冬世代幼虫は蛹化, 羽 化状況調查後成虫は産卵に用い，ふ化幼虫は自然㧍よび 長日（16時間）下での飼育に供試した。また自然日長の 異った時期に用いた第 2 世代および第 3 世代幼虫は, 長

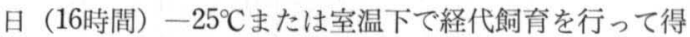
た幼虫である。

2) 採 卵

デシケーター (内径 $12.5 \mathrm{~cm})$ 内に縦に折目をつけたパ ラフィン紙をまいてたて，その底部に水を含ませた脱脂 綿を入れ, 羽化当日から翌日の雌雄の蛾を放飼してパラ フィン紙に産卵させた。産付された卵塊はパラフィン紙 と共に切取り, 小型 (径 $8.5 \mathrm{~cm})$ あるいは大型 $(11.5 \mathrm{~cm})$ のシャーレの底に脱脂綿をしき, ろ紙をのせ水分を与兄 て，切取った卵塊をその上に置き室温または $25^{\circ} \mathrm{C} の$ 定温 器に保護した。卵塊はふ化前に1973年は稲苗を入れた夕゙ ルマ瓶 $(500 \mathrm{~m} \ell$ 容) に移した。1974年と1975年は若いマ コモの苗を入れた大型試験管（径 $3 \times$ 長さ $20 \mathrm{~cm}$ ）の内側 にろ紙とともに切取った卵塊を張りつけ，水分を与光綿 栓をし幼虫をふ化させた。

3) 幼虫の飼育

1973年はダルマ瓶に稲苗を入れ，ふ化時から 3 令期頃 まで集団飼育を行った後, 普通試験管で稲を用いて個体 飼育を行った。1974年と1975年はマコモの若苗を入れた 大型試験管でふ化後10〜15日位まで飼育し，ついで普通 試験管に $3 \sim 5$ 頭あて分飼した後個体飼育を行った。餌 はマコモの根元の部分をつけ長さ $10 \mathrm{~cm}$ 位に切ったものを 用い，幼虫期に $4 \sim 5$ 回取りかえた。稲を用いた場合は そのつど記載した。

長日区は20Wの螢光灯を用いタイムスイッチで日長時 間が16時間になるように調節した。

休眠虫の決定は第 1 世代幼虫はふ化日から約 90 日後, 第 2 世代は約 60 日，第 3 世代は約 50 日後に最終調查を行 